\title{
The role of self-regulation and alienation in Predict educational achievement motivation of students
}

\author{
Vahid Fallahi ${ }^{1}$, Niloofar Mikaeli ${ }^{2}$, Akbar Atadokht $^{3}$, Shirin Ahmadi ${ }^{4}$ \\ 1- PhD student of psychology, School of Psychology and Educational Sciences, University of Mohaghegh \\ Ardabili, Ardabil, Iran (Corresponding Author). \\ E-mail: vahid.fallahi.68@gmail.com \\ 2- Professor of Psychology, Department of Psychology, School of Educational Sciences and Psychology, \\ University of Mohaghegh Ardabili, Ardabil, Iran. \\ 3- Associate Professor of Psychology, Department of Psychology, School of Educational Sciences and \\ Psychology, University of Mohaghegh Ardabili, Ardabil, Iran. \\ 4- PhD student of psychology, Faculty of Educational Sciences,University of Mohaghegh Ardabili , Ardabil, \\ Iran.
}

Received: 10/08/2019

Accepted: 02/12/2019

\begin{abstract}
Introduction: One of the most important components of the life of students is the need for progress.
\end{abstract}

Aim: This study aimed to study the role of self-regulation and alienation in predicting students' motivation was.

Method: This study was correlational The study population included all high school boys and girls schools Pars Abad city administration were studying in the academic year comprised 2017. One hundred and Twenty students were selected from this population through multistage random cluster sampling and they were asked to respond to Questionnaires of self-regulation, alienation academic and achievement motivation. Data were analyzed using Pearson's correlation and multivariate regression tests.

Results: Results showed that Achievement motivation total score of alienation, components of the sense of meaninglessness and disability, isolation negative relationship with selfregulation has a significant positive relationship. Regression analysis also showed that Regression analysis also showed that 48 percent of the variance in student achievement motivation by elements of alienation and self-determination.

Conclusion: The study shows that self-regulation and alienation educational ability to predict achievement motivation as significant. Accordingly, predicting the motivation for student progress through variables such as self-alienation and self-regulation, indicates the need to pay attention to deep and sustained personality structures in future interventions and researches.

Keywords: Self-regulation, Alienation educational, Achievement motivation, Students

\footnotetext{
How to cite this article : Fallahi V, Mikaeli N, Atadokht A, Ahmadi Sh. The role of self-regulation and alienation in Predict educational achievement motivation of students. Shenakht Journal of Psychology and Psychiatry. 2019; 6 (5): 72-82 .URL: http://shenakht.muk.ac.ir/article-1-649-fa.pdf
}

Copyright (C 2018 the Author (s). Published by Kurdistan University of Medical Sciences. This is an open access article distributed under the terms of the Creative Commons Attribution-Non Commercial License 4.0 (CCBY-NC), where it is permissible to download, share, remix, transform, and buildup the work provided it is properly cited. The work cannot be used commercially without permission from the journal. 


\title{
نقش خودتنظيمى و ازخودبيكانكى تحصيلى در بيشبينى انكيزه بيشرفت داشى آموزان
}

\author{
وحيد فلاحى'، نيلوفر ميكائيلى'، اكبر عطادخت!، شيرين احمدى \\ ا.دانشجوى دكترى تخصصى روانشناسى، دانشكده علوم ترييتى و روانشناسى، دانشكاه محقق اردييلى، اردبيل، ايران (مولف مسئول). \\ vahid.fallahi.68@gmail.com : ايميل \\ r. استاد كروه روانشناسى، دانشكده علوم تربيتى و روانشناسى، دانشخاه محقق اردييلى، اردبيل، ايران.

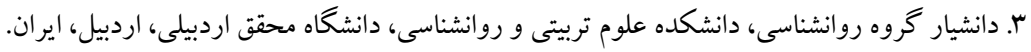

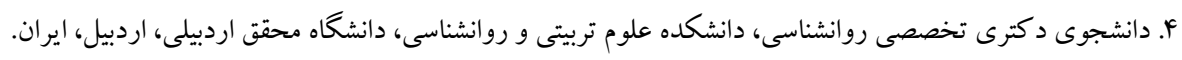

$$
\text { مقدمه: يكى از مهم ترين مؤلفههاى زندگى دانش آموزان نياز به بيشرفت است. }
$$

هدف: يُزوهش حاضر با هدف بررسى نقش خودتنظيمى و ازخودبيخانگى تحصيلى در بيش بينى انگگيزه بيشرفت دانش آموزان انجام كرفت.

روش: اين ئزوهش به روش همبستخى انجام شد. جامعه آمارى يُزوهش حاضر را كليه دانش آموزان دختر و يسر دورهى متوسطه

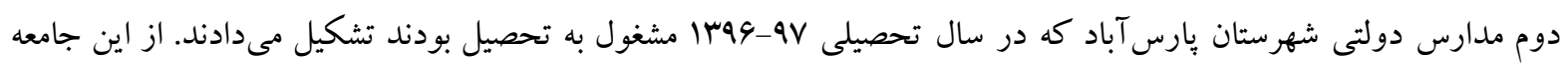

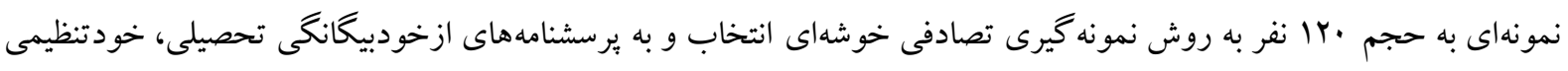

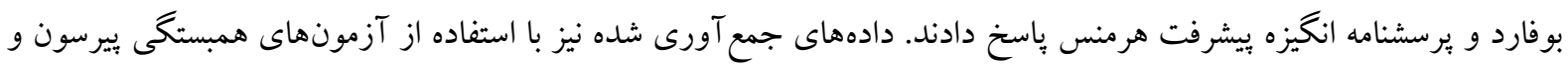
تحليل رگرسيون جند گانه تحليل شد.

يافتهها: نتايج ضرايب همبستخى نشان داد كه انكيزه بيشرفت با نمره كل ازخودبيگانگى و مؤلفههاى احساس بـمعنايى و احساس

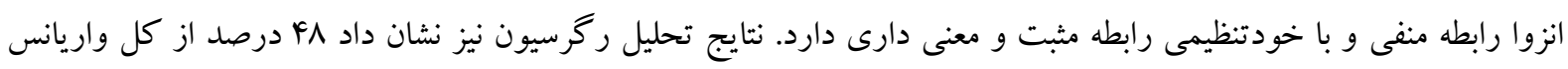
انكيزه بيشرفت به وسيله ازخودبيخانگى تحصيلى و خودتنظيمى تبيين مى وشود. نتيجه كيرى: نتايج اين بزوهش نشان مىدهد كه ازخودبيگانگى تحصيلى و خودتنظيمى مى توانند به صورت معنىدارى انكيزه

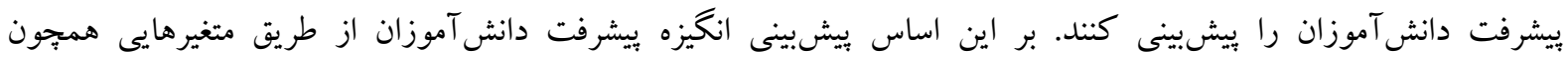

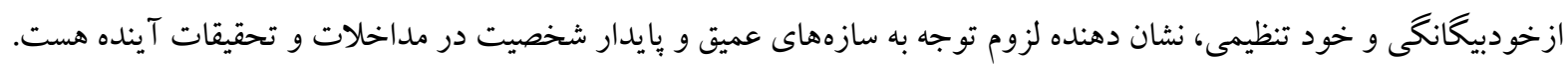
كليدوازهها: خودتنظيمى، ازخودبيگانخى تحصيلى، انخيزه بيشرفت، دانش آموزان 
تكاليفشان به انتخاب از ميان آنها مى يردازند. علاوه بر

اينكه محيط يادگيرى نقش مهمى را در تجهيز دانشآموزان به مهارتهاى خودتنظيمىداراست، ادراك و احساسى كه دانش آموزان نسبت به محيط مو جود دارند و تحت عنوان جو نيز خوانده مى شود، عامل مهمى در اين زمينه محسوب مىشود. عصر كنونى نيازمند افرادى است كه توانايى هدايت يادگيرى خويش را داشته باشند. با توجه به جايگاه و اهميت سيستم آموزشى در هر جامعهاى انتظار تحقق جنين هدفى نيز متوجه نظام آموزشى هست. بر اين اساس تجهيز دانشآموزان به مهارت كنترل و تنظيم گرى ياد گيرىهايشان، تحت اصطلاح كلى (خود تنظيمى" در مدرسه و وراى آن،

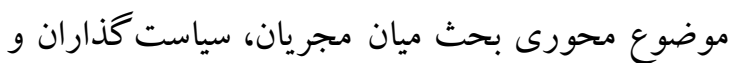
محققان تربيتى را تشكيل مى دهد (آرسال؛ •. (Y).

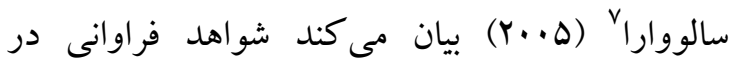
حمايت از اهميت خودتنظيمى به عنوان يك متغير مهم در يادگيرى و ييشرفت تحصيلى دانش آموزان وجود دارد. صمدى (Y.VV) در تحقيقات خود نشان داد خودتنظيمى در يادگيرى دانش آموزان نقش دارد.

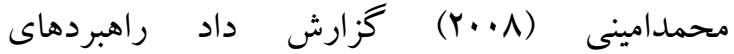
خودتنظيمى در بيشرفت تحصيلى دانشآموزان نقش

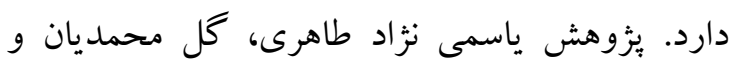

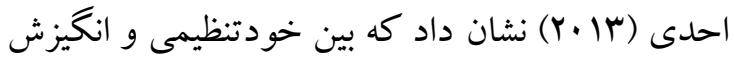
يشرفت دانش آموزان دختر رابطه مثبت و معنىدار وجود دارد و تحقيق رجايى هرندى (· · (Y) نيز در اين زمينه همسو با نتايج يزوهش آنها است. بخشايش، جسمانى و افشانى (19 (Y) در مطالعات خود نشان دادند بين خودتنظيمى و عملكرد تحصيلى دانشآموزان ارتباط مثبت و معنادارى وجود دارد.
يكى از مهمترين مؤلفههاى زندگى دانش آموزان نياز

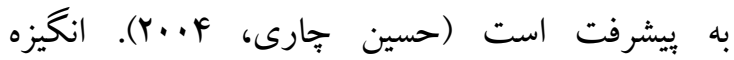
يشرفت' ميل، اشتياق و تلاشى است كه فرد براى دستيابى به يكك هدف يا تسلط به اشياء و امور و يا افراد و انديشهها و رسيدن به يكك معيار متعالى از خود ابراز مى كند (يارسا، 1991). در واقع دانش آموزان و و دانشجويان از طريق انخيزه بيشرفت برانگيخته مىشوند

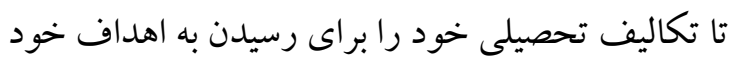
و سطح مشخصى از تخصص، مهارت و موفقيت تكميل

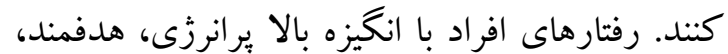
جهتدار و با ثبات دار است (امر ايى،الهى مطلق،عزيزى و بِاهون، (1) (Y). انخيزه بيشرفت را در بسيارى از

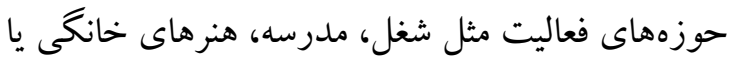
مسابقات ورزشى و قهرمانى مى توان مشاهده كرد و ما

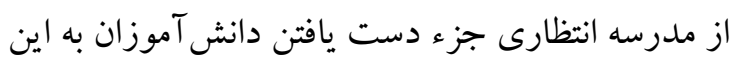

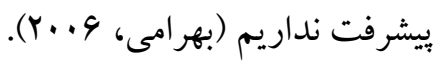
براى كسب انخيزه بيشرفت، ضرورى است كه به زمينه هاى اجتماعى و تحصيلى مختلفى توجه شود. يكى از زمينه هاى مورد توجه روانشناسان و متخصصان تربيتى و يكى از عواملى كه مىتواند با انكيزه يِيشرفت در

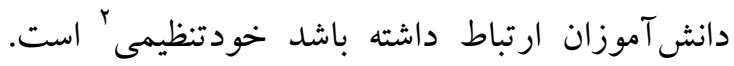
خودتنظيمى عبارت است از افكار، احساسات و اعمال ايجاد شدهاى كه برنامه ريزى شده و به طور منظم جهت دستيابى به اهداف شخصى تنظيم و تعديل شده -

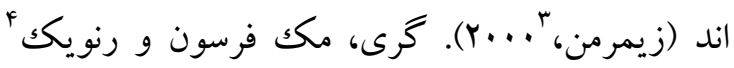

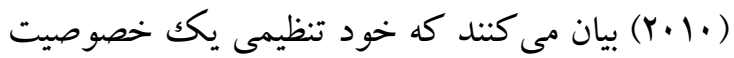
و ويزگ ثى ثابت نيست؛ بلكه مجموعهاى از فرايندهاى

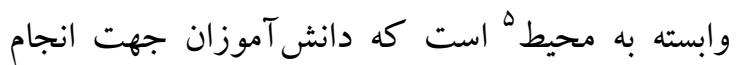

\footnotetext{
- Achivement Motivation

${ }^{2}$ - Self - Reguletion

3 - Zimrman

4- Gary, Mcpherson\& Renwick
}

5 - Context - Specific 
مدارس در امر تعليم و تربيت دانش آموزان دارد

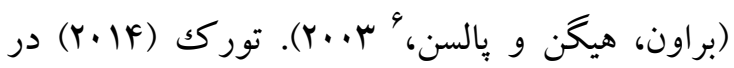
مقالهاى با عنوان (ازخودبيكانكى در تحصيلى" علائم از

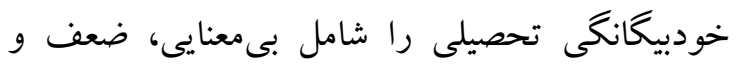
ناتوانى، شكستن قوانين و عدم تفاوت با جامعه مىداند.

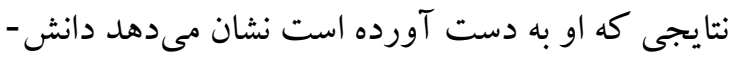
آموزانى كه علائم فوق را تجربه مى كنند از مدرسه،

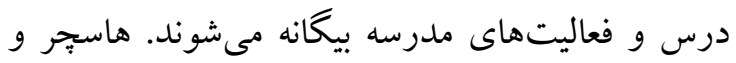

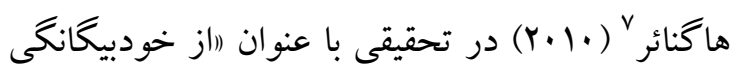
ناشى از مدرسه) نشان دادند كه از خودبيگًانكى ناشى از

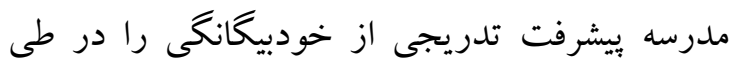

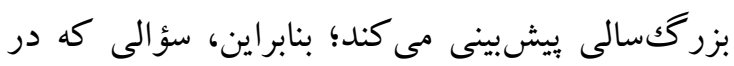
اينجا مطرح مىشود اين است كه آيا بين خودتنظيمى و ازخودبيگانكى تحصيلى (احساس بىمعنايى، احساس ناتوانى و احساس انزوا) و انخيزه ييشرفت در دانش لئسي

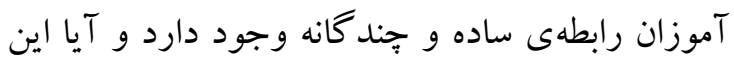
متغيرها مى توانند در انخيزه بيشرفت آنها نقش داشته

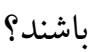

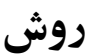

روش يزوهش حاضر توصيفى - همبستخى است. جامعه

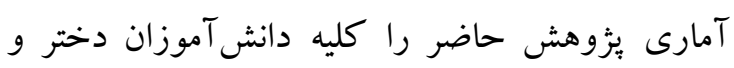
يسر دور0ى متوسطه دوم مدارس دولتى شهرستان ״يارس آباد كه در سال تحصيلى تحصيل بودند تشكيل مىدادند. جون حداقل حجم نمونه در تحقيقات همبستخى ·r نفر به ازاى هر متغير هودي 9. است در اين ئزوهش به دليل متغير بيشبين تعداد

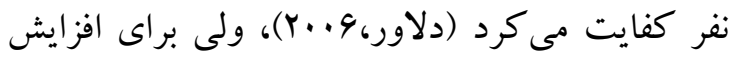

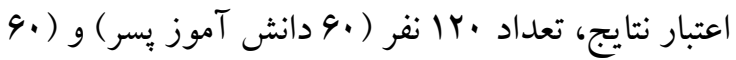
دانش آموز دختر) از اين دانش آموزان به روش نمونه -

\footnotetext{
6- Brown,Higgins \& Paulsen
}

7. Hascher\& Hagenauer
يكى ديخر از مفاهيمى كه درسطح نظام آموزشى مطرح و مرتبط با سطح ييشرفت دانش آموزان است و همبِين از مهمترين مشكلاتى است كه عدهاى از دانش آموزان در طى تحصيل دجار آن مىشوندازاز خود بيكانكى از

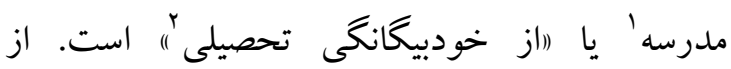

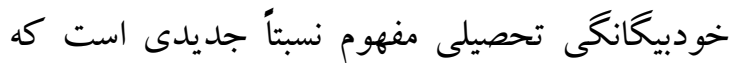
اخيراً به عنوان سازهاى جهت فهم رفتارهاى دانش-

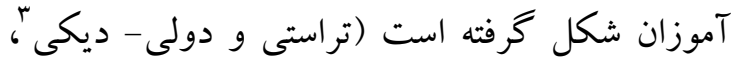
س991). اين بحران به تجربه انزوا از يكك گروه يا فعاليتى

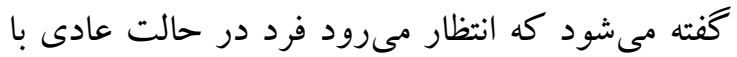
آن گروه احساس همبستگى نموده يا با آن فعاليت

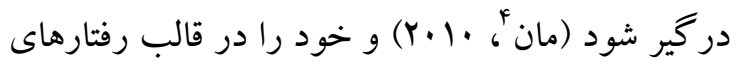
مخربى از قبيل عضويت در كروههاى خلافكار، خشونت خرابكارى يا ولخردى، غيبت از مدرسه و و

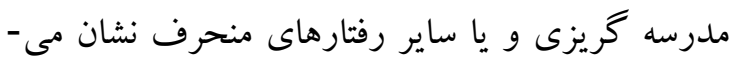

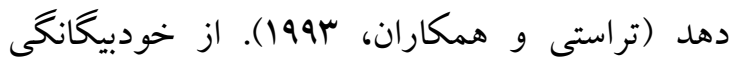
تحصيلى باعث مىشود دانشجويان و دانشآموزان كمترين مشاركت را در فرايندهاى سازمانى داشته باشند. علاوه بر آن ازخودبيگانگى از سازمانهاى آموزشى موجب گريز افراد از فرايندهاى يادگيرى

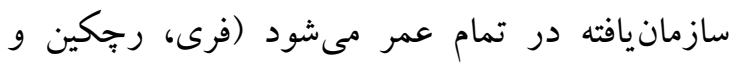

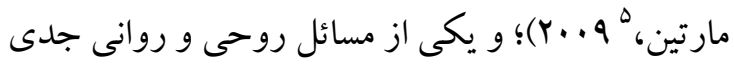
جدى است كه مىتواند تبعات اجتماعى غيرقابل انكارى براى فرد و جامعه داشته باشد (خواجه نوى،

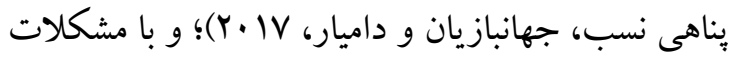

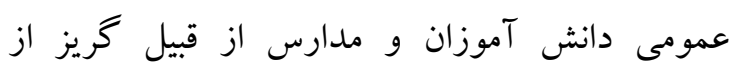
مدرسه، ونداليسم يا خرابكارى و مشاركت كمتر در

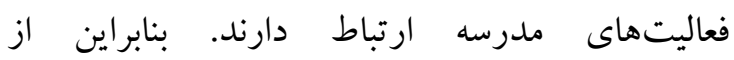

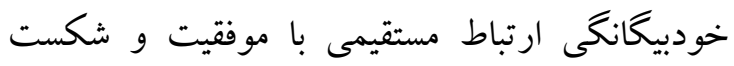

\footnotetext{
- Alienation of Schoo

2- Educational Alienation

3 - Trusty\&Dooley-Dickey

4- Mann

5. Frey, Ruchkin\&Martin
} 
سؤالات در مقياس ليكرت بوده و دو عامل راهبردهاى شناختى و فراشناختى را مىسنجد. روايى و پِايايى اين

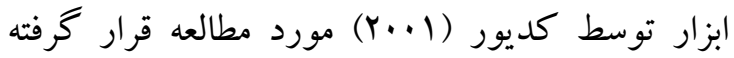
است. روايى سازه اين آزمون با استفاده از ضرايب همبستخى و تحليل عوامل ضرايب همبستكى تفكيكى رونى بين سؤالات برسشنامه در حد مطلوب كزارش شده و ضريب آلفاى كرونباخ جهت سنجش همسانى درونى

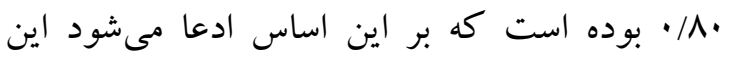
يرسشنامه قادر به يِشيشى نمرههاى واقعى آزمودنىها است. آلفاى محاسبه شده توسط بثزوهشخران • ^/ •است. يرسشنامه ازخودبيكانكى تحصيلى: اين :برسشنامه به

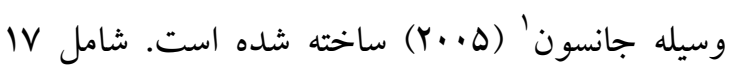
سؤال است كه سه بعد احساس بىمعنايى (سؤالات اتا 9)، احساس ناتوانى (سؤالات V تاYI) و احساس انزوا

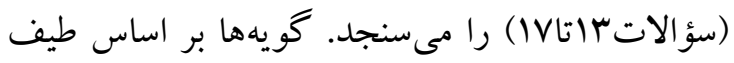
ليكرت ينج درجهاى از كاملاً غلط (1) تا كاملاً درست (ه) تنظيم شده است. ضريب قابليت اعتماد اين مقياس

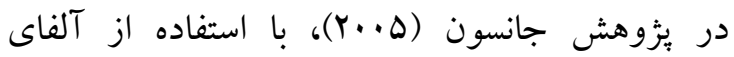
كرونباخ به ترتيب براى كل مقياس NV/ •، احساس انزوا

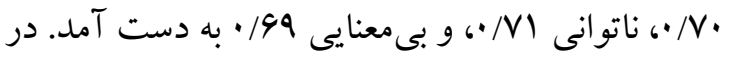
مطالعه قلاوندى غلامى، اكبرى سوره و امانى سارى

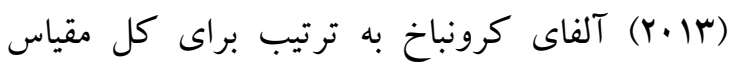

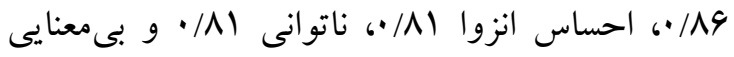

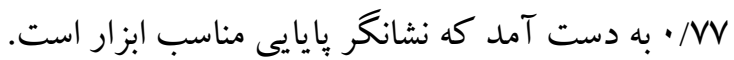
براى روايى اين برسشنامه از روش تحليل عاملى تأييدى

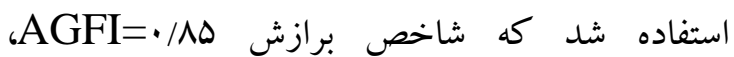
$\mathrm{CFI}=\cdot / 9 \uparrow, \mathrm{RMSEA}=\cdot / \cdot \vee \quad$,GFI $=\cdot / \wedge q$ نشانكر برازش مناسب اين برسشنامه است (قلاوندى و

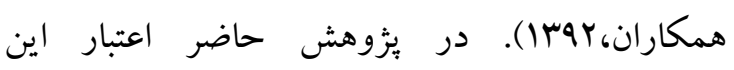
يرسشنامه با روش ضريب آلفاى كرونباخ \ل/ • به دست

\footnotetext{
${ }^{1}$-Johnson
}

كيرى تصادفى خوشهاى از جامعه آمارى فوق انتخاب شد. اشتغال به تحصيل در مقطع متوسطه دوم در زمان يُوهش و تمايل دانش آموزان براى شركت در

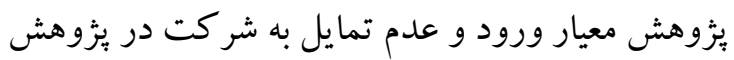
معيار خروج بود. روند اجراى يثوهش حاضر بدين صورت بوده است كه بعد از كسب مجوز از آموزش و ״رورش شهرستان يارس آباد، ابتدا ليست تمامى مدارس

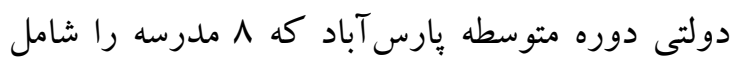
مىشد تهيه و جهار مدرسه (Y دييرستان دخترانه و r دبيرستان بسرانه) از بين آنها با روش نمونه ميرى

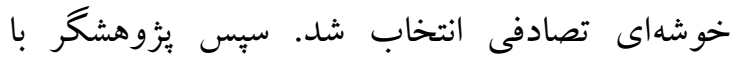
حضور در مدارس و ضمن هماهنكى با مدير و دبيران مدارس مربوطه، ابتدا هدف تحقيق براى آنها بيان شد و سبس از آنها خواسته شد به برسشنامهاى انگيزه يشرفت، خودتنظيمى و از خودبيكانكى ياسخ دهند. در اين يُزوهش، تمام آزمودنىها براى شركت در

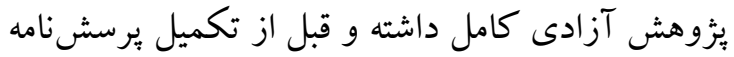
جهت رعايت ملاحظات اخلاقى اهداف يُوهش به آنها از طريق معلم مدرسه و مشاور مدرسه توضيح داده شد و به آنها اطمينان داده شد كه اطلاعات جمع آورى شده به صورت گروهى تحليل خواهد شد. به منظور تجزيه و تحليل دادهها نيز با استفاده از نرم افزار

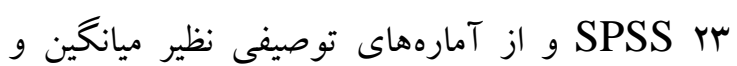
انحراف استاندارد و تحليلهاى استنباطى همجِون

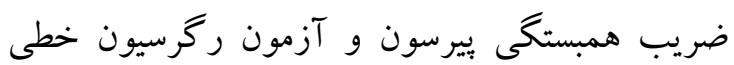
جند كانه استفاده شد.

\section{ابزار} يرسشنامه خود تنظيمى بوفارد: برسشنامه YN سؤالى

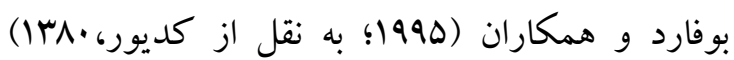
ابزارى است جهت سنجش خود - تنظيمى كه بر اساس نظريه شناختى اجتماعى بندورا طرح شده است. 
يزّوهش شركت داشتند. از لحاظ رشته تحصيلى نيز MF نفر (

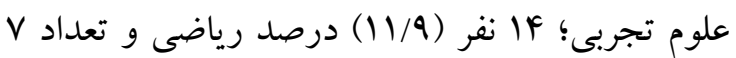
نفر عمومى (ه/Q) درصد بودند كه هنوز رشته خاصى را

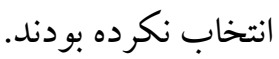
براى تجزيه و تحليل دادهها از ضريب همبستكى بيرسون و رگرسيون خطى جند گانه (به روش كام به كام) استفاده شد. قبل استفاده از اين آزمونها، مفروضههايى كه استفاده از آنها را مجاز مىشمارند، مورد بررسى قرار گرفت. مفروضهى وجود رابطهى خطى بين متغيرهاى بيشبين و ملاكك با توجه به نمودار يراكنش متغيرها (نشانگر وجود رابطهى خطى بين متغيرهاى بيشبين و ملاكك)، مفروضهى نرمال بودن توزيع دادهها با استفاده از آزمون كولموكروف اسميرنف (ه •/P>)، مفروضهى استقلال باقيماندهها با استفاده از آمارهى دوربين -واتسون (قرار گيرى در بازه -

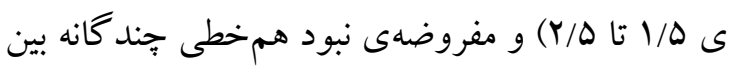
متغيرهاى مستقل با استفاده از شاخص تولرانس (بزرگ تر از / /)، مورد تأييد قرار گرفت؛ بنابراين، از ضريب همبستگى بيرسون و ركرسيون جند گانه براى تجزيه و تحليل دادهها استفاده شد.
يرسشنامه انتيزه يُشرفت هرمنس: اين يرسشنامه به صورت و Y جمله ناقص ساخته شده كه به دنبال هر جمله ناتمام جند گزينه داده شده است. شيوهى نمرهكذارى در اين آزمون بر اساس ياسخ آزمودنىها به سؤالات و به اين صورت است كه به خزينها بر حسب انكيزش بيشرفت از زياد به كم و يا از كم به زياد،

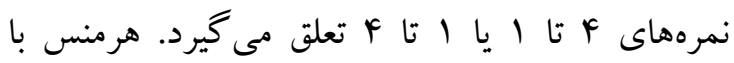
استفاده از دو روش آلفاى كرونباخ و باز آزمايى اعتبار آزمون را به ترتيب AF/ • و /AY/ محاسبه كرده است

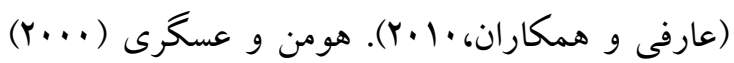
يزوهشى را با هدف ساخت، اعتباريابى، رواسازى و هنجاريابى آزمون انخيزه ييشرفت روى گرووه نمونهاى به حجم سV •ا ( •وه دختر و ساه بسر) از دانش آموزان دبيرستانى شهرستان ساوه و حومه كه با روش نمونه بردارى جند مرحلهاى انتخاب شدند، اجرا نمودند. ضريب اعتبار آزمون با استفاده از فرمول آلفاى

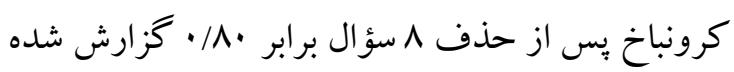
است كه تائيد كننده اعتبار مطلوب آزمون است.

إفتها

تعداد • rا دانش آموز بِر (·4 نفر) و دختر (·4 نفر)

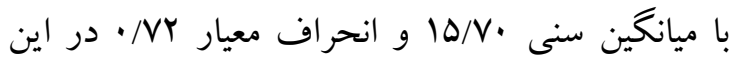

جدول ا ميانكين، انحراف معيار و ضرايب همبستكى نمرات آزمودنى ها در هريكى از مؤلفههاى

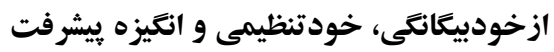

\begin{tabular}{|c|c|c|c|c|c|c|c|}
\hline (9) & $(\Delta)$ & $(\boldsymbol{f})$ & $(\Gamma)$ & $(r)$ & (1) & $\begin{array}{c}\text { (انحر اف معيار) } \\
\text { (انغين }\end{array}$ & متغيرها \\
\hline & & & & & 1 & $\begin{array}{l}r q / 99 \\
( \pm \wedge / \Delta 9)\end{array}$ & تحصيلى( ازبيعانگى \\
\hline & & & & 1 & $\cdot / \mathrm{V} 9_{\text {米粠 }}$ & $( \pm r / \cdot r) \| / \Delta F$ & احساس بى معنايى(r) \\
\hline & & & 1 & 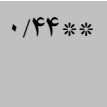 & $\cdot / \Lambda \mid *$ & $\begin{array}{l}19 / \cdot V \\
( \pm F / V r)\end{array}$ & ناتوانى(r) \\
\hline & & 1 & $\cdot / r \Delta_{\text {䉼 }}$ & 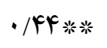 & $\cdot N \cdot$ 光䉽 & $( \pm r / \Delta F) q / F r$ & انزوا(f) \\
\hline
\end{tabular}




\begin{tabular}{|c|c|c|c|c|c|c|c|}
\hline & 1 & 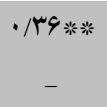 & $-\cdot / \mu F_{* * *}$ & $-\cdot /$ 个兼莎 & $-\cdot / 千 \wedge$ 兼棌 & $\begin{array}{l}F V / \Delta Q \\
q / \Delta Q\end{array}$ & خودتنظيمى(ه) \\
\hline 1 & $91 \cdot$ 米光 & $-\cdot / r Y * *$ & 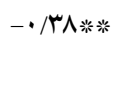 & 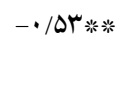 & $-\cdot / \Delta \Delta \Delta_{\text {米米 }}$ & $\begin{array}{l}q \cdot / r q \\
V / r r\end{array}$ & انتيزه بيشرفت(ع) \\
\hline
\end{tabular}

|

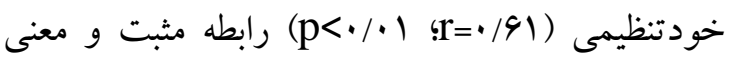

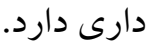

نتايج جدول ا نشان مىدهد كه انگيزه بيشرفت با نمره كل ازخودبيگانگى (ه) بى معنايى (r=)

جدول r نتايج تحليل ركرسيون جند گانه براى ييش بينى انكيزه پيشرفت بر اساس متغيرهاى پيش بين

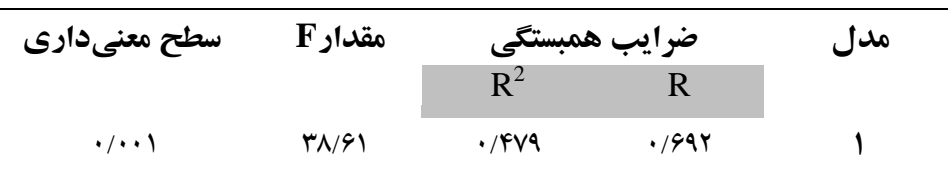

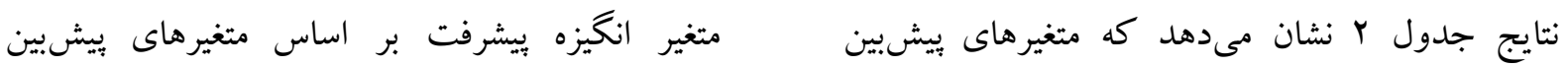

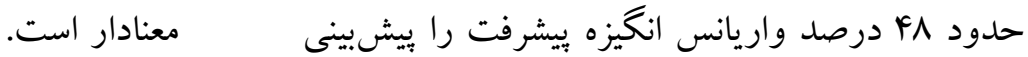
مى كند. نسبت F نيز بيانكر اين است كه ركرسيون

\begin{tabular}{|c|c|c|c|c|c|c|}
\hline \multirow[t]{2}{*}{ سطح معنىدارى } & $\mathbf{t}$ & 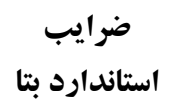 & & غير استاندارد & متيش بير هاى & متغير ملاكك \\
\hline & & & استاندارد & $\mathrm{B}$ & & \\
\hline.$/ \cdot 1$ & $F \cdot / l F$ & & $r / V$. & $1 \cdot N / 4$. & مقدار ثابت & \multirow[t]{5}{*}{ انكيزه هيشرفت } \\
\hline.$/ \cdot 1$ & $-4 \cdot 1 \cdot 9$ & $-\cdot|4|$ & $\cdot / Y F$ & $-\cdot / 99$ & احساس بى معنايى & \\
\hline.$/ \cdot \Delta$ & $-1 / N 1$ &.$- / 19$ &.$/ I F$ & $-\cdot / Y F$ & ناتوانى & \\
\hline.$/ 11$ & $-1 / 91$ &.$- / 10$ &.$/ 19$ & $-\cdot / r$ & انزوا & \\
\hline.$/ \cdot 1$ & V/RY & $.19 \cdot 9$ & $\cdot / \cdot 19$ & .1949 & خود تنظيمى & \\
\hline
\end{tabular}

انكيزه بيشرفت در دانش آموزان را بيشبينى (T=V/Tr)

نتايج جدول ب نشان مىدهد كه احساس بى معنايى با

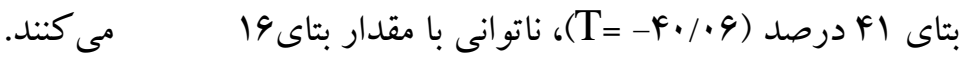
درصد ( و خودتنظيمى با مقدار بتاى ا9 درصد 
خودتنظيمى است را افزايش دهند. همجِنين افرادى كه از خودتنظيمى بالايى برخوردارند، مىتوانند به طور

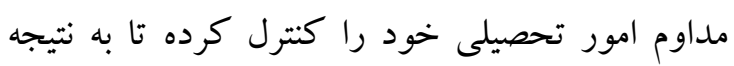
مطلوبى برسند. به طور ييوسته بر ييشرفتشان نظارت

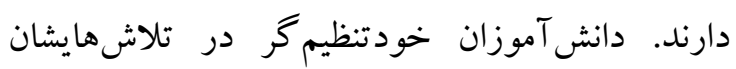

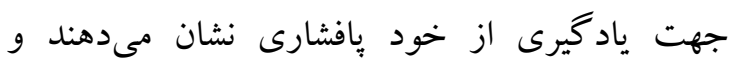

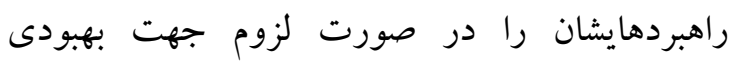
ياد گيرىشان تغيير مىدهند. محققان دريافتهاند كه رهان ياد گيرى خودتنظيمى با موفقيت در مدرسه ارتباط دارد

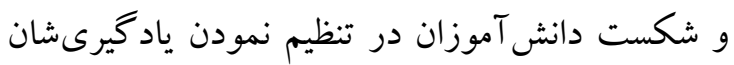

يكك دليل اصلى براى عدم موفقيت تحصيلى است. نتايج آزمون همبستخى ييرسون نشان داد إنكيزه

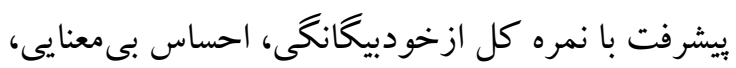
ناتوانى و انزوا رابطه منفى و معنىدارى دارد. نتايج

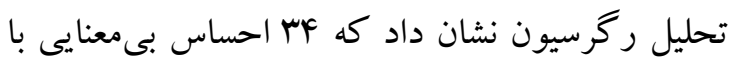
بتاى أل درصد، ناتوانى با مقدار بتاى 19 درصد و انزوا با مقدار بتاى ها درصد انخيزه بيشرفت در دانش آموزان را ييشبينى مى كنند.

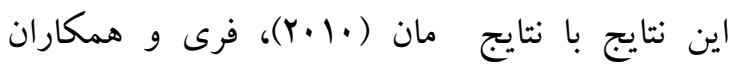
(Y.q) همكاران (Y...

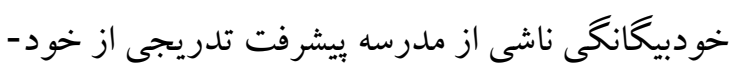

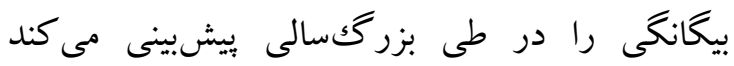

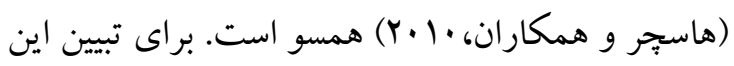
يافته مى توان جنين مطرح كرد كه از خودبيگانكى يكى از مهمترين مشكلاتى است كه عدهاى از دانش آموزان در طى تحصيل دجار آن مىشوند. اين بحران تجربه

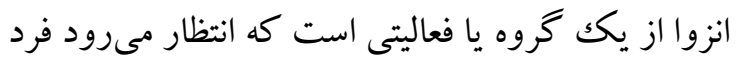
در حالت عادى با آن گروه احساس همبستگى نموده يا

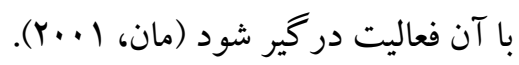
به علت اينكه دانش آموزان بخش اعظم زندكى خود را را در مدرسه مى گذرانند، نقش مدرسه و روابط درون آن آن
اين بزوهش با هدف بررسى نقش خودتنظيمى و از

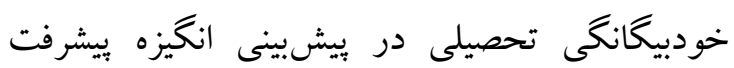

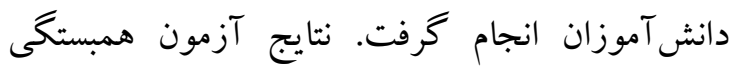
ييرسون نشان داد انخيزه بيشرفت با نمره كل خود تنظيمى رابطه مثبت و معنىدارى دارد. نتايج تحليل ركرسيون نشان داد كه خودتنظيمى با مقدار بتاى

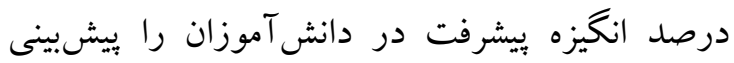

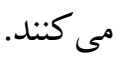

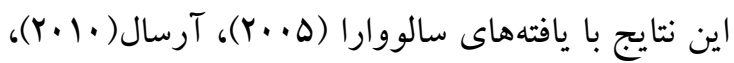

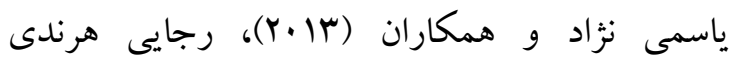

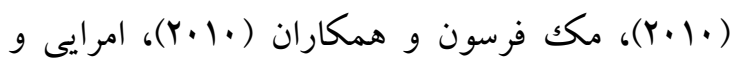
همكاران (Yl11)، بخشايش و همكاران (Y.19)،

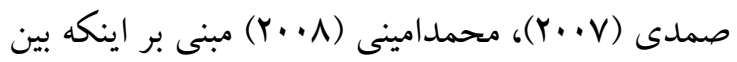
مؤلفههاى باور به خود كارآمدى، انخًيزه بيشرفت و و سيستم يادگيرى خود-تنظيمى در بين دانشجويان ارتباط معنادارى وجود دارد يوسف (11) همخوان است. در تبيين اين فرضيه مىتوان كفت خودتنظيمى يكى از مقولههايى است كه در آن به نقش فرد در جريان تنظيم هيجان توجه مىشود (تامسون، 1999)؛ به بيان ديخر خودتنظيمى به معناى سر كوب هيجانها و ونهان

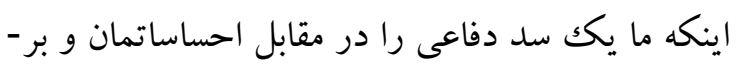

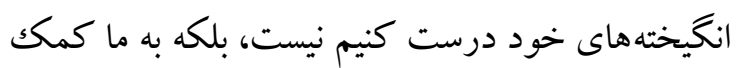

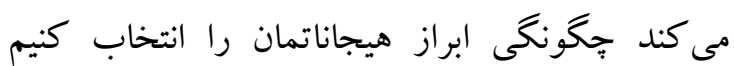

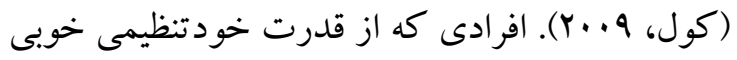
برخوردار هستند به راحتى مىتوانند فشارهاى اجتماعى كه ناشى از دوستان و همسالانشان است را كاهش داده و به عبارتى مىتواند از يس خو استه هاى نامعقول آنها

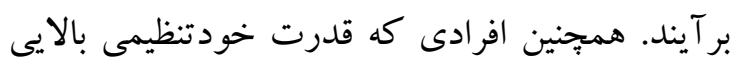
دارند مى توانند هيجانات خود را شناخته و با برنامهريزى بهتر استرس كمترى را تجربه كنند و به تبع آن به ييشرفت بالاترى دست بيدا كنند؛ بنابراين مىتوانند

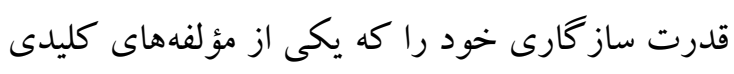


شخصيت، همجيون صفات بنيادين و سازههاى كلى شخصيت و بررسى ارتباط جند گانه اين متغيرها با ابعاد مختلف انكيزه بيشرفت در كروههاى تفكيكك شده و وارد ساختن متغيرهاى هويتى و دمو گرافيك به عنوان متغيرهاى تعديل كننده در يثزوهشهايى با اهداف هماهنگك با تحقيق حاضر، مى تواند از جمله يِيشنهادهاى بنيادين براى محققان اين حوزه در يزوهشهاى آتى باشد.

\section{سياسگز ارى}

بدين وسيله از همكارىهاى مشفقانه رياست آموزش و يرورش، مدير، مشاور و معلمان مدارس شهرستان يارس آباد كه در اجرا و انجام يزوهش ما را يارى نمودند و كليه دانش آموزان شركت كننده در بزّوهش يُ كمال تشكر و قدردانى مىشود.

References

Amrai K, Elahimotlagh S, Azizi ZH, \& Pahan H.(2011). The Relationship Between Academic Motivation And academic Achievement Students. JoumalOf Social And Behavioral Sciences, 15,399-402.

Arefi M, Rahmani J, Safai S. (2010). The Relationship between Elements and Dimensions of School Cultures with Advancement Motivation in Middle School Students in Mobarakeh, Joumal of Curriculum Planning, Knowledge and Research in Education Sciences, No. 27 , Pp. 116-101.

Bahrami F. (2006), "A Study on the Relationship Between the Progressive Motivation of High School Girls and Boys in Isfahan City with their School Characteristics", Educational and Psychological Research, No. 2.

Bakhshayesh A, Jesmani S, Afshani A. (2016). The Effect of Smart Schools on Computer

Anxiety, Self-regulation and Academic Performance of High School Students
در آماده سازى آنان براى زندگى اجتماعى و شغلى نقش كليدى دارد. با وجود اين، دانش آموزان زيادى قبل از اينكه به طور كامل براى زندگى اجتماعى و شغلى آماده شوند، به علت بيكانكى از تحصيل از مدرسه فرارى شده و تركى تحصيل مى كنند. درواقع ازخودبيگانكَى باعث ايجاد احساس عدم دلبستكى به مدرسه به عنوان سازمانى براى تعليم و تربيت و عدم دستيابى به مدارج تحصيلى بالاتر مىشود (فرى و همكاران، 9 ج.r). در همين راستا اگر معلمان و ساير دانش آموزان بتوانند در تعاملات اجتماعى خود به نحو

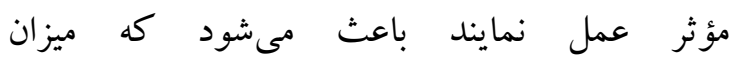
ازخودبيكانكى تحصيلى كاهش يافته و دانش آموزان ترغيب شوند تا توجه ويزهاى به امر تحصيل نمايند. وقتى كه تعامل در مدرسه به حداكثر خود برسد، دانش آموزان در ساير امور فوق برنامه مشاركت مى كنند و اين عامل جذابيت مدرسه را براى دانش آموزان افزايش مىدهد و باعث بالا رفتن انكيزه بيشرفت در آنها مىشود.

\section{نتيجه Fيرى}

اين ثيزوهش با محدوديتهايى همراه بود. استفاده از مقياس خود كز ارشى مى تواند از عوامل تهديد كننده روايى درونى در يزوهش حاضر باشد، همگن بودن بيش از حد نمونه از لحاظ سن، تحصيلات و مرتبه اقتصادى- اجتماعى، مىتواند تعميم يذيرى نتايج يثزوهش حاضر را محدود سازد. بيشبينى انگيزه بيشرفت دانش آموزان از طريق متغيرهايى همجون ازخودبيگانگى و خود تنظيمى، نشان دهنده لزوم توجه به سازههاى عميق و يايدار شخصيت در مداخلات و و تحقيقات آينده است. از همين رو طراحى و اجراى يزّوهشهايى با متغيرهاى بيشبين در ديخر حوزههاى 
Comparing with Non-Smart Schools. Educational New Thoughts, Volume 2, Issue 11, 48-34.(Persian).

Brown M, Higgins K, \& Paulsen P. (2003). Adolescent Alienation. What IsIt And What Can Educatiors Do About It? Joumal of Interventionin School and Clinic. 39(1),3-90

Delavar A. (2006). Theoretical and scientific resources of research in humanities and social sciences. (Persian).

Frey A, Ruchkin V, Martin A, \& Schwab-Stone M. (2009). Adolescents In Transition School And Family Characteristics In The Development Of Violent Behavior Entering High School. Joumal of Child Psychiatry And Human Development.40(1),1-13.

Gary E, Mcpherson J, Renwick M. (2010). A Longitudinal Study Of Self- Regulation In Childrens Musical Practice. Joumal Of Music Educational Research,3(2).Pp 169186.

Ghalavandi H, Gholami MT, Akbari Surah P, Amani Sarabi Baglou J. (2013). School Culture and Academic Self-Alienation: The Role of Mediating Essential Psychological Needs, Culture Strategy, No. 24. (Persian).

Hascher T, \& Hagenauer G. (2010). Alienation Form School. International Joumal of Educational Research .49(2),220-232.

Hooman HA, Asgari A. (2000). Preparation and standardization of the test of motivation for progress. Quarterly joumal of psychological research, 11, 9-32. (Persian).

Hosseini Chari M. (2004). "Investigating the Elements and Dimensions of School Culture and its Impact on CognitiveBehavioral Consequences in Primary School Students of Shiraz", PhD thesis, Shiraz University. (Persian).

Johnson GM. (2005). Student Alienation, Academic Achievement, and WebCTUse. Journal of Educational Technology \&Society, 8(2), 179-189.

Kadivar P. (2001). Self-efficacy, self-study and intelligence in the improvement of high school students 'students' education, Joumal of Educational Sciences and Psychology, Volume 10, Issue 2-1, pp. 58-45. (Persian).
Khaij Noori B, Panahi Nasab S, Jahanbaziyan S, \& Demayar I. (2017). The Relationship between Parent Styles and Adolescents' Ability (A Case Study of Shiraz Girl and Son High School Students in 2010-2011). Joumal of Social Sciences Islamic Azad University, Shoushtar Branch.10(2):1-22. (Persian).

Koole SL. (2009). The psychology of emotion regulation: An integrative review. Cognition and Emotion, 23(1), 441.

Mann SJ. (2010). Altemative Perspective On The Student Experience: Alienation And Engagement. Studies In Higher Education .26.7-13.

Mohammad Amini Z (2008). Relationship between self-regulation leaming strategies and motivational beliefs with student's academic achievement. (Persian).

Parsa M. (1998). Educational Psychology, First Edition; Tehran, Scientific Publication.

Rajai Harandi Z (2010). "The Relationship Between Progressive Motivation and Self-Control with Students' Academic Performance." Graduate Degree. Islamic Azad University, Islamic Azad University, Central Branch, Faculty of Educational Sciences and Psychology. (Persian).

Robert S. (2006). Educational Psychology; Theories and Applications, Translated by Seyyed Mohammadi, 2006, Tehran: Ravan Publication.

Rovai AP, \& Wighting MJ. (2005). Feelings Of Alienation And CommubityAmang Higher Education Students In A Virtual Classroom. Joumal Intemet And Higher Education. $8(2), 97-110$.

Salovaara H. (2005). Achievemen Goals And Cognitive Learning Strategies In Dynamic Contexts Of Leaming,Academic Dissertation To Be Presented With The Assent Of The Faculty Of Education, University OfOulu,For Public Discussion In Faculty Of Education, Department Of Educational Sciences And Teacher Education.

Samadi M. (2007). The effect of self-regulation strategies of parents and self-regulated ways in student's leaming on self-esteem of high school girl students in Tehran. New 
Thoughts of Education, Volume 3, Issue 1, Spring 2007, Page 137-153. (Persian).

Thompson RA. (1994). Emotion regulation: A theme in search of definition.Monographs of the society for research in child development, 59(2-3), 25-52.

Trusty J, \& Dooley-Dickey K. (1993). Alienation from school: An exploratory analysis of elementary and middle school students' perceptions. Joumal of Research and Development in Education. 26(4), 232-242.

Turk F. (2014). Alienation in Education. Intemational Journal of Educational Policies 8 (1), pp. 4158. ISSN: 1307-3842.

Yasiminejad P, Taheri M, Golmohammadian M, Ahadi H. (2013). "Self-regulatory relationship with the motivation of progress and academic achievement of high school girl students in Tehran", Two Journal of Research in Shahed University, 20th Century, New course, number 3. (Persian). 